\title{
Ocena inwestycji na Warszawskiej Giełdzie Towarowej w okresie od stycznia 2002 roku do lipca 2004 roku
}

\section{Wprowadzenie}

Giełdy towarowe, uznawane są za jedne z najbardziej rozwiniętych rynków formalnych. W latach $90 . \mathrm{XX}$ wieku, po prawie czterdziestoletniej przerwie, ponownie pojawily się na polskiej scenie gospodarczej. Jest ich około 30 i działają na podstawie przepisów nawiązujących do ustawy z 1928 roku. Mają na ogół, charakter lokalny, a formą i sposobem działania przypominają tradycyjne aukcje i przetargi. Towary będące przedmiotem obrotu są raczej przypadkowe. Brakuje również charakterystycznej dla giełd na świecie płynności obrotów, co oznacza, iż nie ma pewności, że dany towar pojawi się na giełdzie na dwóch kolejnych sesjach. W przeciwieństwie do rodzimych, giełdy towarowe na świecie działają na zasadzie wielkich korporacji i obce im są problemy, z którymi stykają się nasze giełdy.

$\mathrm{Na}$ giełdach towarowych handluje się nie tylko towarami. Zawierane sa również transakcje finansowe, a przedmiotem obrotu są także kontrakty terminowe. W Polsce ten ostatni sposób handlu dopiero raczkuje. Generalnie jednak, w przypadku giełd towarowych, możemy mówić o dużej różnorodności ,jednostek negocjacyjnych". Alternatywnym do giełd sposobem inwestowania są wszelkiego rodzaju fundusze i lokaty bankowe. Z teorii rynków finansowych wiadomo, że ten ostatni rodzaj inwestycji obarczony jest najmniejszym ryzykiem. Uczestnicy rynku nie stanowią jednak monolitu i mają zróżnicowany stosunek do ryzyka, stąd też nie brakuje chętnych do inwestowania na giełdach, w tym również towarowych. Najnowsze teorie związane $\mathrm{z}$ rynkami finansowymi do problemu „inwestorów” podchodzą bardzo poważnie, gdyż okazuje się, że duży wpływ na sytuację na rynku mają zarówno wydarzenia polityczne i gospodarcze, jak również związane z nimi reakcje inwestorów. Meandry zachowań inwestorów tłumaczy psychologia poznawcza, która stała się podstawą nowego nurtu w teorii finansów, zwanego behawioralnym. Najnowsze trendy 
związane z teorią rynków finansowych opiszemy w części drugiej. W części trzeciej spróbujemy przeanalizować, $w$ jakim stopniu najnowsze teorie sprawdzają się $w$ polskich warunkach. W tym celu przeprowadzimy analizę zmian cen towarów, którymi obracano na WGT w okresie od stycznia 2002 roku do lipca 2004 roku i zastanowimy się nad rolą wydarzeń oraz związanych z nimi zachowań inwestorów w kształtowaniu się owych cen.

\section{Krótki przegląd teorii rynków finansowych: od Bacheliera do Kahnemana}

Giełdy towarowe, a coraz częściej towarowo-pieniężne, w ogólnym zarysie działaja na zasadach analogicznych do tych, na jakich funkcjonuja giełdy papierów wartościowych. Inne sq̨ wprawdzie jednostki negocjacyjne i w związku z tym odmienny jest sposób formułowania i rozliczania transakcji, ale pozostałe elementy są bardzo podobne. Warto zatem w skrócie przypomnieć, w jaki sposób w ciagu ostatniego stulecia rozwijała się teoria rynków finansowych oraz dlaczego w ostatnich latach kluczową rolę w teorii inwestowania kładzie się na „kondycje psychiczną" inwestora, nie zaś na procesy i mechanizmy związane $\mathrm{z}$ funkcjonowaniem giełdy.

Przez dhugie lata w teorii rynków finansowych obowiązywała hipoteza rynku efektywnego (Efficient Market Hypothesis - EMH). Efektywność rynku wiązała się z przekonaniem, że jego uczestnicy zachowują się w sposób racjonalny w sensie maksymalizacji swojej użyteczności. W rzetelny sposób przetwarzają wszystkie napływające informacje, które niemalże natychmiast znajdują odzwierciedlenie w cenie akcji. U podstaw tej hipotezy leży założenie, że szeregi czasowe zmian cen walorów mają charakter losowy. W 1959 roku M.F.M. Osborne w tekście zatytułowanym „Brownian Motion in the Stock Market” (Ruchy Browna na rynku akcji) zasugerował, że zmiany cen akcji mają charakter błądzenia przypadkowego, a konkretnie dają się opisać tym samym procesem, co ruchy cząstek w cieczy (ruchy Browna). Kontynuował on badania zapoczątkowane w 1900 roku przez Louisa Bacheliera. Osborne założył, że decyzje inwestorów motywujące każdą transakcję są niezależne, a co za tym idzie - niezależne są również zmiany cen walorów.

Od początku lat 60 . hipotezę rynku efektywnego zaprzestano wiązać z modelem błądzenia przypadkowego. Okazało się, że założenie dotyczące niezależności kolejnych kursów akcji jest zbyt rygorystyczne, a ponadto, w ogóle nie zostały uwzględnione założenia dotyczące preferencji uczestników rynku i ich stosunku wobec ryzyka. W 1965 roku Paul Smuelson powiązał hi- 
potezę rynku efektywnego $\mathrm{z}$ modelem martyngałowym. Swoje rozważania oparł na założeniu, że oczekiwane stopy zwrotu $z$ akcji są jednakowe $\mathrm{i}$ stałe w czasie. Uczestnicy rynku z kolei mają jednakowe preferencje i są neutralni wobec ryzyka.

Formalna i najczęściej cytowana definicja rynku efektywnego pochodzi z prac Eugene Famy [1970, 1976]. Rynek efektywny, według niego, to taki, na którym ceny zawsze odzwierciedlają w pełni dostępną informację, a ceny aktywów finansowych mają charakter losowy. Fama odrzucił natomiast powiązania efektywności rynku z możliwością opisania zachowania stóp zwrotu za pomocą martyngału. Faktem jednak jest, że założenie efektywności rynku stało się podstawą do stworzenia wielu znanych modeli rynków kapitałowych, takich jak na przykład CAPM (Capital Asset Pricing Market) czy ATP (Arbitrage Theory Pricing), jak również nowoczesnej.teorii portfela stworzonej przez Harry'ego Markowitza [Jajuga 1996].

Wkrótce jednak po sformułowaniu hipotezy rynku efektywnego pojawily się wątpliwości co do tego, czy jest ona prawdziwa. Już w 1953 roku Maurice Kendall, badając brytyjski rynek akcji bawełny oraz pszenicy, doszedł do wniosku, że nie istnieją żadne prawidłowości pomiędzy zmianami cen i trudno przesądzać czy są losowe, czy też nie. Zmiany cen bawełny i pszenicy w USA na przestrzeni 60 lat obserwował Benoit Mandelbrot. Wyniki swoich badań ogłosił w latach 70. XX wieku, przy czym sugerował, że przebiegi różnych $z$ pozoru nieprzewidywalnych procesów nie sq̨ wcale przypadkowe. Zauważył między innymi, że niewielkie zmiany cen $\mathrm{z}$ dnia na dzień następowały $\mathrm{w}$ tym samym rytmie co zmiany w dłuższym czasie.

Obserwacje szeregów czasowych na rynkach kapitałowych skłoniły naukowców do przypuszczeń, że mają oni do czynienia ze skomplikowanymi układami, złożonymi z wielu zmiennych powiązanych ze sobą w sposób nieliniowy. Zaobserwowano, że trajektorie zmian cen do zhudzenia przypominają fraktale, a same układy, $\mathrm{z}$ natury deterministyczne, w określonych sytuacjach zachowują się chaotycznie. W ten sposób powstała hipoteza rynku fraktalnego (Fractal Market Hypothesis - FHM), która stanowi alternatywę dla hipotezy rynku efektywnego. Szczegóły tej hipotezy zostały dopracowane w Research Institute of Applied Economics w Zurychu. Hipoteza rynku fraktalnego, w przeciwieństwie do hipotezy rynku efektywnego, uwzględnia wpływ informacji i długości horyzontu czasowego na zachowanie się poszczególnych inwestorów. Mówi również, że globalny rynek składa się z dużej liczby uczestników o różnych horyzontach czasowych, a ceny odzwierciedlają kombinację handlu zarówno krótko-, jak i długoterminowego.

Teoria chaosu, a wraz z nią hipoteza rynku fraktalnego dobrze modeluja rynek kapitałowy, ale od strony mechanizmów, nie zaś odczuć inwestorów. 
Teoria ta ma wiele wad, a najważniejșzą jest fakt, że nie uwzględnia w dostateczny sposób często spontanicznych zachowań inwestorów. Ponadto, możliwe jest prognozowanie przyszłych cen walorów giełdowych, ale wyłącznie w krótkich okresach, co nie do końca satysfakcjonuje zarówno analityków, jak inwestorów. W naturalny więc sposób badacze doszli do wniosku, że dotychczasowe rozważania dotyczące rynków finansowych w niedostateczny sposób uwzględniają czynnik ludzki.

Problem ten został dostrzeżony przez Daniela Kehnemana i Amosa Tversky'ego [Kahneman, Tversky 1976, 1979]. Obaj badacze są psychologami, którzy stworzyli teorię perspektyw, a ta z kolei dała początek nowemu nurtowi teorii finansów, zwanemu behawioralnym. Ów nurt, w przeciwieństwie do EMH i FMH, uwzględnia psychologiczne uwarunkowania decyzji inwestycyjnych. Wszelkie anomalie występujące na rynku tłumaczy brakiem racjonalności zachowań jego uczestników. Badacze ci stwierdzili, że człowiek silnie reaguje na wszelkiego rodzaju bodźce i jest skłonny do przeceniania strat i niedoceniania wygranych. Ponadto, uczestnicy rynku przywiązuja nieadekwatną wage do informacji, przyswajaja je stopniowo, a także pod ich wpływem dokonują wyborów w taki sposób, jakby mieli niestandardowe preferencje.

Bazując na pracach Kehnemana i Tversky'ego, Werner de Bondt, Richard Thaler oraz inni [Tyszka i inni 2004] rozwinęli nurt behawioralny we wspólczesnej teorii finansów. Przebadali oni odstępstwa od hipotezy rynku efektywnego, a następnie wysnuli wniosek, że większość anomalii na rynkach zdarza się właśnie za sprawą inwestorów. Przyjęli więc, że efektywność rynku nie jest, a wręcz nie może być cechą immanentną. $W$ badaniach związanych $z$ teorią rynków behawioralnych kluczowe okazały się również publikacje związane $\mathrm{z}$ analizą hazardu. Zachowania hazardzistów, jako specyficznego rodzaju inwestorów, są bardzo interesujące $\mathrm{z}$ punktu widzenia psychologii, ekonomii, a także teorii podejmowania decyzji. Na podstawie obserwacji zachowań hazardzistów udało się opisać wiele zjawisk, które odnoszą się również do zachowań inwestorów. Wśród nich możemy wymienić na przykład złudzenie gracza czy też złudzenie kontroli. Pierwsze z nich dotyczy sytuacji, po której inwestor wierzy, że po dostatecznie długiej serii tych samych wyników powinny one ulec zmianie. Tymczasem większość zdarzeń nie zależy od siebie. Drugie ze zjawisk thumaczy się tym, że jeśli jakiekolwiek przypuszczenie inwestora zostaje potwierdzone określonymi wynikami kilka razy z rzędu, a dodatkowo dobrze rozpoznal on problem, to ma on zhudzenie kontroli nad przebiegiem zachodzących zdarzeń. Podobnych zjawisk związanych z zachowaniami inwestorów opisano i zdefiniowano znacznie więcej [Tyszka i inni 2004]. Nowe spojrzenie na problemy związane $\mathrm{z}$ hazardem dała seria badań z psychologii poznawczej, określanych mianem ,heurystyki i zniekształcenia" (heurystics 
and biases). Heurystyki obejmują między innymi szeroki zakres błędów ludzkiego wnioskowania. Najbardziej znane to: iluzja dostępności (availability) im łatwiej inwestor kojarzy zdarzenia, tym, wedhug niego, prawdopodobieństwo ich zajścia jest większe - oraz reprezentatywności (representativeness) oceny przyszłych zdarzeń uzależnia od dobrze rozpoznanych cech zbioru możliwych wariantów.

Badania nad behawioralną teorią finansów są kontynuowane i w coraz większym stopniu thumaczą zjawiska, które zachodzą na rynkach finansowych. Mówią również o pułapkach psychologicznych, z którymi stykają się na co dzień inwestorzy.

\section{Analiza cen towarów na WGT od stycznia 2002 roku do lipca 2004 roku}

W niniejszej części spróbujemy zastanowić się, w jakim stopniu wydarzenia pociaggające za sobą niekoniecznie racjonalne zachowania inwestorów wpływały na ceny towarów na WGT w okresie od stycznia 2002 roku do lipca 2004 roku. Zastanowimy się również, czy rodzimy rynek towarów możemy uznać za efektywny, czy też nie.

W tabelach 1-3 prezentujemy średnie ceny towarów w poszczególnych miesiącach w latach 2002-2004. Zauważmy, że w niektórych miesiącach wiele towarów w ogóle nie było notowanych. Potwierdza się więc „własność” typowa dla polskich giełd, mówiąca o tym, że nie może być na nich mowy o płynności obrotów, a ów fakt możemy uznać za jedną z anomalii przeczącą teorii efektywności. Są okresy, w których transakcje na pewne towary w ogóle nie dochodzą do skutku.

W badanym okresie w przypadku niektórych towarów notowanych na WGT można było zaobserwować znaczące ruchy cen. Przykładem może być cukier. Rysunek 1 zawiera wykres cen cukru od czerwca 2002 roku do maja 2004 roku.

Widzimy, że niemalże przez cały badany okres cena cukru kształtowała się na poziomie $0,8 \mathrm{zł}$ za kilogram. We wrześniu 2002 roku wzrosła do $1,31 \mathrm{zł}$ za kilogram $\mathrm{i}$ był to wzrost sezonowy, zwiazzany $\mathrm{z}$ zamieszaniem na rynku cukrowniczym (a konkretnie likwidacją i prywatyzacją wielu cukrowni). Sytuacja się unormowała i w kolejnych miesiącach cena była stabilna. Drugi znaczący wzrost cen cukru nastapił w kwietniu 2004 roku i związany był $z$ wejściem Polski do Unii Europejskiej. Ceny cukru w Unii Europejskiej są bowiem wyższe niż $w$ Polsce $\mathrm{i} w$ związu $\mathrm{z}$ tym gwałtownie wzrósł popyt na ten towar. W niektórych sklepach cukier był nawet reglamentowany, a jego cena dochodziła do $4 \mathrm{zł}$ za kilogram. Na giełdzie cukier w maju 2004 roku kosztował $2,12 \mathrm{zł}$ za 
Tabela 1

Średnia miesięczna cena niektórych towarów notowanych na WGT w 2002 roku (skrót b.n. oznacza brak notowań)

\begin{tabular}{|c|c|c|c|c|c|c|c|c|c|c|c|c|}
\hline Towar & 空 & 烦 & 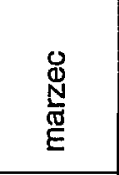 & 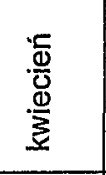 & "ृ & 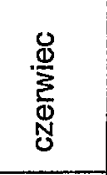 & 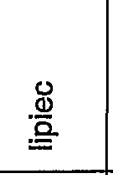 & $\begin{array}{l}\frac{c}{0} \\
\frac{0}{2} \\
\frac{0}{\infty}\end{array}$ & 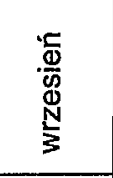 & 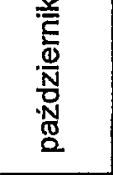 & 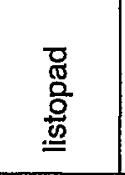 & $\begin{array}{l}\text { 동 } \\
\text { 옴 } \\
\text { 늠 }\end{array}$ \\
\hline Cukier biały zł/kg & b.n. & b.n. & b.n & b.n & 1,75 & 1,16 & 0,94 & 1,126 & 1,068 & 0,844 & 0,8 & 0,8 \\
\hline $\begin{array}{l}\text { Ćwierćtusze wołowe } \\
\text { średnio } \mathrm{z} t / \mathrm{kg}\end{array}$ & 4,613 & 4,5 & 4,501 & 4,006 & 3,9 & 3,013 & 3,0 & 2,524 & 2,177 & 3,28 & 2,9 & 2,1 \\
\hline $\begin{array}{l}\text { Groch konsumpcyjny } \\
\text { zł/t }\end{array}$ & 740,0 & 680,0 & 698,0 & 687,5 & 670,0 & 610,0 & 600,0 & 529,74 & b.n. & 705,0 & 692,27 & b.n. \\
\hline $\begin{array}{l}\text { Masło na średnio } \\
\mathrm{z} f / \mathrm{kg}\end{array}$ & 8,3 & 5,96 & 5,58 & 5,62 & 3,5 & b.n. & b.n. & b.n. & b.n. & b.n. & 7,806 & 7,7 \\
\hline $\begin{array}{l}\text { Póltusze wieprzowe } \\
\text { średnio } z \Varangle / k g\end{array}$ & 6,0 & 4,501 & 4,537 & 4,506 & 4,5 & 3,422 & 3,628 & 4,32 & 3,51 & 3,51 & 3,5 & 3,008 \\
\hline $\begin{array}{l}\text { Pszenica konsump- } \\
\text { cyjna średnio zł/t }\end{array}$ & 550,0 & 550,0 & 550,0 & 550,0 & 550,0 & 550,0 & 550,0 & b.n. & b.n & b.n & 430,0 & 453,0 \\
\hline $\begin{array}{l}\text { Żyto konsumpcyjne } \\
\text { średnio zł/t }\end{array}$ & 410,07 & 410,56 & 410,04 & 411,0 & 410,0 & 410,0 & 382,5 & 355,0 & b.n. & b.n. & 349,04 & 352,59 \\
\hline
\end{tabular}

Źródło: opracowanie własne na podstawie www.wgt.com.pl 
Tabela 2

Średnia miesięczna cena niektórych towarów notowanych na WGT w 2003 roku (skrót b.n. oznacza brak notowań)

\begin{tabular}{|c|c|c|c|c|c|c|c|c|c|c|c|c|}
\hline Towar & ญ्र & $\stackrel{\vec{Z}}{\Xi}$ & 畩 & $\frac{\frac{0}{0}}{\frac{0}{0}}$ & 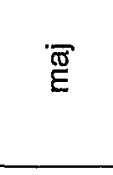 & 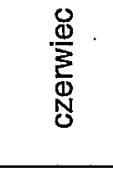 & 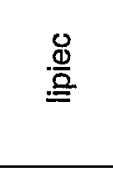 & $\frac{\frac{\cdot}{0}}{\frac{0}{0}}$ & $\begin{array}{l}\frac{\cdot}{0} \\
\frac{0}{0} \\
\stackrel{N}{N} \\
\frac{5}{3}\end{array}$ & 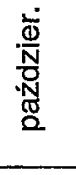 & 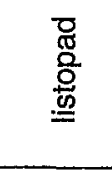 & 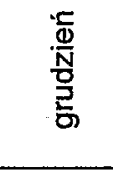 \\
\hline Cukier bialy zł/kg & 0,80 & 0,80 & 0,80 & 0,81 & 0,85 & 0,8 & 1,05 & 0,87 & 0,8 & 0,8 & 0,8 & 1 \\
\hline $\begin{array}{l}\text { Ćwierćtusze wo- } \\
\text { łowe średnio zł/kg }\end{array}$ & 1,83 & 1,84 & 2,2 & 2,52 & b.n. & b.n. & 2,21 & b.n. & 3,25 & b.n. & b.n. & b.n. \\
\hline $\begin{array}{l}\text { Groch konsump- } \\
\text { cyjny zł/t }\end{array}$ & b.n. & 740,0 & 746,67 & 760,0 & 733,33 & 650,0 & 640,1 & b.n. & b.n. & b.n. & b.n. & b.n. \\
\hline $\begin{array}{l}\text { Konserwa mięsna } \\
\text { zt/szt }\end{array}$ & b.n. & 1,62 & b.n. & 1,40 & 1,28 & 1,11 & 2,56 & 3,23 & 2,99 & b.n. & 1,55 & b.n. \\
\hline $\begin{array}{l}\text { Masło w blokach } \\
\mathrm{z} \mathrm{l} / \mathrm{kg}\end{array}$ & 7,70 & 7,70 & 7,70 & 7,56 & 7,50 & b.n. & 7,94 & b.n. & b.n. & b.n. & b.n. & b.n. \\
\hline $\begin{array}{l}\text { Półtusze wie- } \\
\text { przowe średnio } \\
\text { zł/kg }\end{array}$ & 3,01 & 3,02 & 3,01 & 3,02 & 2.52 & 2,52 & 3.87 & 3,31 & 3,42 & 3,21 & 3,09 & 3,13 \\
\hline $\begin{array}{l}\text { Pszenica kon- } \\
\text { sumpcyjna śred- } \\
\text { nio zł/t }\end{array}$ & 400,1 & 412,8 & 436,14 & 461,97 & 540,32 & 544,03 & 524,03 & b.n. & 526,86 & b.n. & 659,13 & 688,30 \\
\hline $\begin{array}{l}\text { Żyto konsumpcyj- } \\
\text { ne średnio zł/t }\end{array}$ & 353,49 & 354,5 & 369,15 & 400,23 & 514,21 & 475,02 & 443,65 & b.n. & b.n. & b.n. & b.n. & 515,44 \\
\hline
\end{tabular}

Źródło: opracowanie własne na podstawie www.wgt.com.pl 


\section{Tabela3}

Średnia miesięczna cena towarów notowanych na WGT w 2004 roku (skrót b.n. oznacza brak notowań)

\begin{tabular}{|c|c|c|c|c|c|c|c|}
\hline Towar & 怘 & $\underline{\Xi}$ & 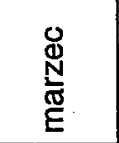 & 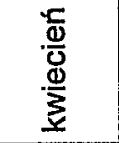 & "ָ & 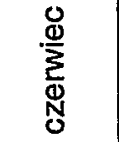 & 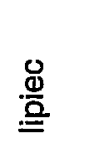 \\
\hline Cukier biały zt/kg & 0,96 & b.n. & 0,80 & 2,12 & 0,8 & b.n. & b.n. \\
\hline $\begin{array}{l}\text { Groch konsumpcyjny } \\
\text { zl/t }\end{array}$ & 950,0 & 950,0 & 905,92 & b.n. & b.n. & b.n. & b.n. \\
\hline $\begin{array}{l}\text { Konserwa mięsna } \\
\text { (ARR) zt/szt. }\end{array}$ & 1,39 & b.n. & 1,08 & 1,09 & 1,08 & b.n. & b.n. \\
\hline $\begin{array}{l}\text { Kukurydza paszowa } \\
\text { zł/t }\end{array}$ & 612,5 & 630,0 & 630 & b.n. & b.n. & b.n. & b.n. \\
\hline $\begin{array}{l}\text { Półtusze wieprzowe } \\
\text { średnio } \mathrm{z} / \mathrm{kg}\end{array}$ & 3,24 & 3,64 & 4,95 & 5,64 & b.n. & b.n. & b.n. \\
\hline $\begin{array}{l}\text { Pszenica konsump- } \\
\text { cyjna średnio zł/t }\end{array}$ & 706,25 & 722,5 & 715 & 702,74 & 720 & 689,38 & b.n. \\
\hline Żyto średnio zł/t & 535,22 & b.n. & 530 & 539,12 & 514,0 & 515,0 & 486,0 \\
\hline
\end{tabular}

Źródło: opracowanie własne na podstawie www.wgt.com.pl

kilogram (tab. 3). Po wejściu Polski do Unii Europejskiej, a więc w czerwcu 2004 roku, cena ponownie spadła, przy czym spadek ten bardziej znaczacy był na giełdach niż $w$ handlu detalicznym. Tak więc w kwietniu 2004 roku cena wzrosła w stosunku do marca aż o 265 procent. Jest to absolutny rekord. Kto więc nabył cukier w kwietniu bądź wcześniej, ten mógł niemalże potroić zainwestowaną kwotę. Taki sukces finansowy nie byłby możliwy do osiagnięcia w tym okresie na giełdzie papierów wartościowych. Potwierdza się zatem jedna $\mathrm{z}$ tez wysunięta przez twórców finansów behawioralnych, że wydarzenia mog̨ znacząco wpływać na zachowania inwestorów, a tym samym zmiany cen towarów.

Kolejnym towarem zasługującym na uwage jest wołowina. Zamieszanie związane z chorobą Creutzfelda-Jakoba, potocznie zwaną ,chorobą wściekłych krów", spowodowało gwaltowny spadek zainteresowania tym towarem. O ile w latach 2002-2003 ćwierćtusze wołowe były jeszcze przedmiotem transakcji na WGT, to w 2004 roku w ogóle nimi nie handlowano, co świadczy o nieefektywności rynku towarowego w Polsce (tab. 3). Był to zapewne rezultat spadku ,pogłowia krów". Po wejściu Polski do Unii Europejskiej okazało się jednak, ze ceny skupu poszły do góry. Najwięcej zdrożały wołowina i mleko. W 2003 roku rolnicy sprzedawali żywiec po $2,1 \mathrm{zł}$ za kilogram, a wiosną 2004 roku po $4,6 \mathrm{zt}^{1}$. Z relacji

\footnotetext{
${ }^{1}$ Dane podajemy za Newsweekiem 37/2004 z dnia 12.09.2004, P. Puch, A.R. Potocki, Wieś wstaje $z$ kolan, s. 13-16.
} 


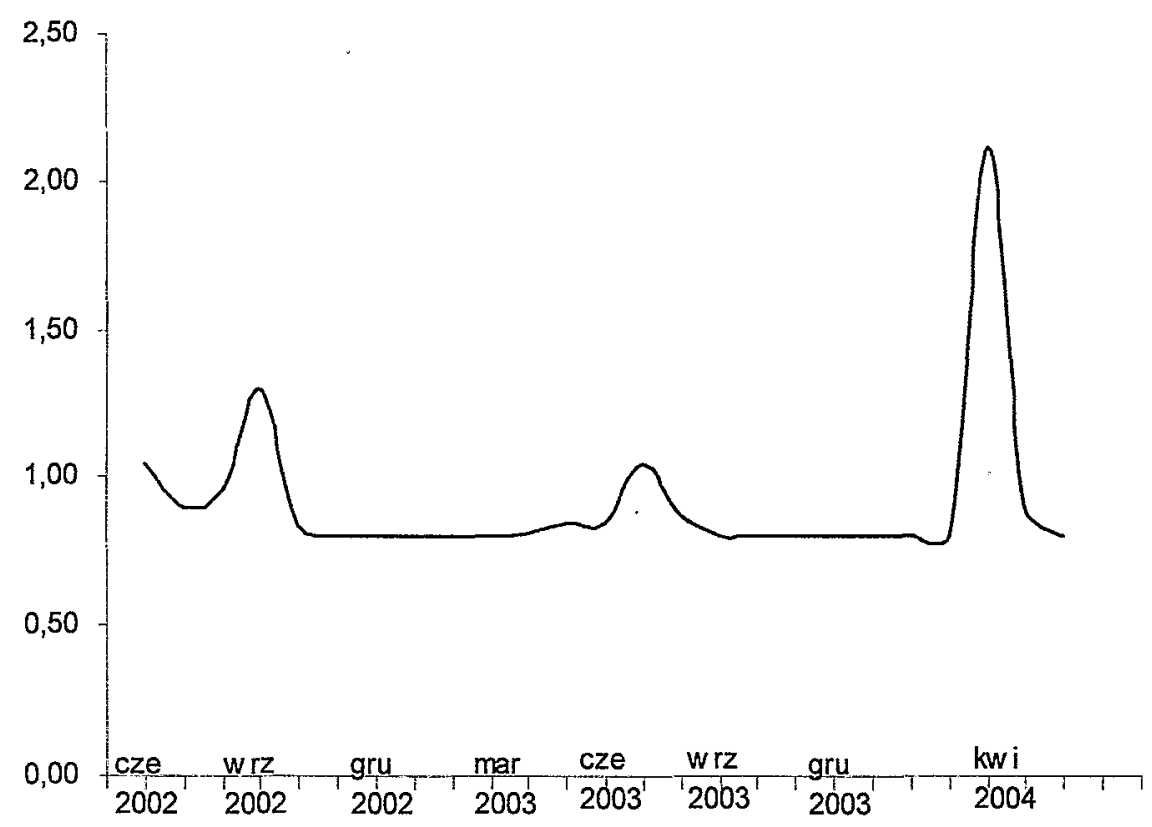

\section{Rysunek 1}

Ceny cukru na WGT od czerwca 2002 do maja 2004

Źródło: opracowanie własne na podstawie www.wgt.com.pl

producentów rolnych wiadomo, że wiosną roku większość transakcji załatwiono poza obszarem giełdy. Rolnicy twierdzą nawet, że popyt na bydło był tak duży, iż „,kupcy z Europy" bezpośrednio w gospodarstwach rolnych dokonywali transakcji, przy tym zainteresowani byli wszystkim, co miało „kopyta i rogi". Podobnie rzecz sie miała z produkcją wieprzowiny. W 2003 roku jej cena wynosiła 2,3 zł za kilogram, a wiosną 2004 około 4,5 zł.

\section{Podsumowanie}

$\mathrm{Na}$ podstawie analizy danych z WGT z okresu od stycznia 2002 roku do lipca 2004 roku widzimy, że produkcja rolna oraz handel towarami mogą być opłacalne. W tym okresie ponadnormatywne zyski były możliwe do osiagnięcia zarówno przez inwestorów, jak również producentów rolnych. Nie wynika to bynajmniej z efektywności naszego rynku towarowego, wręcz przeciwnie: na polskim rynku towarowym nie było mowy ani o efektywności transakcyjnej, ani też informacyjnej. Nie było bowiem płynności obrotów i transakcje na gieł- 
dzie nie dochodziły do skutku. Ponadto, informacja o planowanym wejściu Polski do Unii Europejskiej znana była wszystkim. W związku z tym wiadomo było, że skoro ceny towarów różnią się, to można spodziewać się znaczących wahań cen. Jednak niewielu inwestorów było tym faktem zainteresowanych (ów fakt potwierdzają nieodbiegające od normy obroty giełdowe). Wydarzenie historyczne, jakim było wejście Polski do Unii okazało się zaskoczeniem zarówno dla inwestrów giełdowych, jak i konsumentów. Wytrawni ,gracze giełdowi" z całą pewnością wyszli na swoje, gdyż zysk rzędu 265\% (w ciagu miesiąca) nie był możliwy do osiagnięcia poprzez jakąkolwiek inną inwestycję.

Widzimy więc, że niektóre elementy zaprezentowane przez twórców teorii finansów behawioralnych sprawdzają się w naszych warunkach giełdowych o wiele bardziej niż w jakimkolwiek innym miejscu na świecie. Ponadto, rodzimym inwestorom o wiele bardziej niż rachunek prawdopodobieństwa, przydaje się szczegółowa analiza wydarzeń oraz umiejętność przewidywania tego, co w związku z nimi uczynią inni uczestnicy rynku.

\section{Literatura}

DREWIŃSKKI M., 1997: Giełdy towarowe, PWE, Warszawa.

JAJUGA K., JAJUGA T., 1996: Inwestycje. Instrumenty finansowe. Ryzyko finansowe. Inżynieria finansowa, Wydawnictwo Naukowe PWN, Warszawa.

KEHNEMAN D., TVERSKY A., 1979: Prospect theory: an analysis of decision under risk, Econometrica, Vol. 47, No. 2, 263-292.

Praca zbiorowa pod red. T. Tyszki, 2004: Psychologia ekonomiczna, Gdańskie Wydawnictwo Psychologiczne, Gdańsk.

\section{The Evaluation of Investments at the Warsaw Commodity Exchange from January 2002 to July 2004}

\section{Abstract}

Nowadays the commodity exchange offers not only a wide range of operations such as trade in commodities but also future contracts and other types of financial transactions. While at the stock exchange one can encounter mainly shares, the commodity exchange epitomizes an impressive variety of negotiable units. Mutual funds and deposits, which are an alternative way of investing, also play a relevant role on the financial market. From economical point of view deposits are burdened with the smallest risk. 
According to the modern financial theory, the attitude towards a risk is considered as a very important aspect of the situation on the market. Not only behaviour of the investors but also political and economical events determine the situation on the market. The behaviour of the investors is analysed by the cognitive psychology, which is associated with a new behavioural current in financial theory, which is called the behaviour finance.

The aim of this paper is to check, if it is worth to invest at the commodity exchange. The analysis is carried out on the basis of the data from Warsaw Commodity Exchange in the span of 3 years: 2002-2004. 